Free and for all? A comparative study of programs with user fees in North

American and Danish public libraries

By: Mia Høj Mathiasson and Noah Lenstra

Mathiasson, M.H. and Lenstra, N. (2020). Free and for all? A comparative study of programs with user fees in North American and Danish public libraries. Library Management, 41(2). doi: 10.1108/LN-08-2019-0053

Made available courtesy of Emerald Publishing: http://dx.doi.org/10.1108/LM-08-2019$\underline{0053}$

This work is licensed under a Creative Commons Attribution-NonCommercial 4.0 International License.

Abstract:

Purpose. As a research topic within the field of LIS, programs in public libraries are underexplored and the question of user fees for programs has not previously been addressed.

Design/methodology/approach. This article compares data collected from two individually conducted studies of public library programs in North America and Denmark to enrich our understanding of user fees in relation to programs.

Findings. The comparative analysis shows both similarities and deviations regarding the levying of fees for library programs. While paying a fee to attend a program is rather normal in Denmark it is more of a fringe idea in North America.

Research limitations/implications. By exploring a previously under-studied facet of contemporary public librarianship, this article opens up new avenues for inquiry regarding how the relative accessibility and availability of programs relate to theoretical discussions about programs as essential public library services.

Practical implications. This article provides library managers with needed information about how to conceptualize the roles of programs as essential public library services.

Social implications. As programming surges to the fore in contemporary public librarianship, the levying of user fees has social implications in terms of social equity and the public library ethos of free and equal access for all.

Originality/value. This article is the first study of user fees for public library programs, as well as among the first cross-national comparisons of programming as a dimension of public librarianship.

Keywords: library finance | charging | user fees | public librarianship | library programs | comparative study 
Article:

$* * *$ Note: Full text of article below 
Free and for all? A comparative study of programs with user fees in North American and Danish public libraries

\begin{tabular}{|r|l|}
\hline Journal: & Library Management \\
\hline Manuscript ID & LM-08-2019-0053.R1 \\
\hline Manuscript Type: & Research Paper \\
\hline Keywords: & $\begin{array}{l}\text { Library finance, Charging, User fees, Public librarianship, Library } \\
\text { programs, Comparative study }\end{array}$ \\
\hline \multicolumn{2}{|l}{} \\
\end{tabular}




\section{Article Title Page}

Free and for all? A comparative study of programs with user fees in North American and Danish public libraries

\section{Author Details:}

Mia Høj Mathiasson

Department of Communication; University of Copenhagen; Denmark

\section{Noah Lenstra}

Department of Library \& Information Science; University of North Carolina at Greensboro; USA

Corresponding author: Noah Lenstra

njlenstr@uncg.edu

\section{Biographical Details:}

Mia Høj Mathiasson is a PhD Candidate at the Department of Information Studies, University of Copenhagen. The data for this article has been collected as part of her PhD project on the history, development and terminology of public library programs in Denmark.

Noah Lenstra is an Assistant Professor of Library and Information Science at the University of North Carolina at Greensboro. His research focuses on community engagement and health-related programming in public libraries.

\section{Structured Abstract:}

Purpose. As a research topic within the field of LIS, programs in public libraries are under-explored and the question of user fees for programs has not previously been addressed.

Design/methodology/approach. This article compares data collected from two individually conducted studies of public library programs in North America and Denmark to enrich our understanding of user fees in relation to programs.

Findings. The comparative analysis shows both similarities and deviations regarding the levying of fees for library programs. While paying a fee to attend a program is rather normal in Denmark it is more of a fringe idea in North America.

Research limitations/implications. By exploring a previously under-studied facet of contemporary public librarianship, this article opens up new avenues for inquiry regarding how the relative accessibility and availability of programs relate to theoretical discussions about programs as essential public library services.

Practical implications. This article provides library managers with needed information about how to conceptualize the roles of programs as essential public library services.

Social implications. As programming surges to the fore in contemporary public librarianship, the levying of user fees has social implications in terms of social equity and the public library ethos of free and equal access for all.

Originality/value. This article is the first study of user fees for public library programs, as well as among the first cross-national comparisons of programming as a dimension of public librarianship.

Keywords: library finance; charging; user fees; public librarianship; library programs; comparative study

Article Classification: Research Paper

For internal production use only

Running Heads:

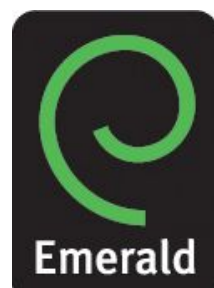




\title{
Free and for all? A comparative study of programs with user fees in North American and Danish public libraries
}

\begin{abstract}
Purpose - As a research topic within the field of LIS, programs in public libraries are underexplored and the question of user fees for programs has not previously been addressed. Design/methodology/approach - This article compares data collected from two individually conducted studies of public library programs in North America and Denmark to enrich our understanding of user fees in relation to programs.

Findings - The comparative analysis shows both similarities and deviations regarding the levying of fees for library programs. While paying a fee to attend a program is rather normal in Denmark it is more of a fringe idea in North America.

Research limitations/implications - By exploring a previously under-studied facet of contemporary public librarianship, this article opens up new avenues for inquiry regarding how the relative accessibility and availability of programs relate to theoretical discussions about programs as public library services.

Practical implications - This article provides library managers with needed information about how to conceptualize the roles of programs as public library services.

Social implications - As programming surges to the fore in contemporary public librarianship, the levying of user fees has social implications in terms of social equity and the public library ethos of free and equal access for all.
\end{abstract}

Originality/value - This article is the first study of user fees for public library programs, as well as among the first cross-national comparisons of programming as a dimension of public librarianship.

Keywords: Library finance, Charging, User fees, Public librarianship, Library Programs, Comparative Study.

Article Type: Research paper.

\section{Introduction}

"Very often ... charges have been levied for things for which the librarian or the board of trustees was not really in sympathy" (Shoham, 1998, p. 40). 
Programs as diverse as reading circles, lectures, community meals, and yoga classes constitute an important dimension of public libraries in the United States of America and beyond. A 2018 study commissioned by the American Library Association (ALA) (2018) finds that citizens, and thus funders, increasingly see public libraries as places that offer “activities and entertainment you can't find anywhere else in the community" (p. 8). The U.S. Institute of Museum \& Library Services (2019) states that "public library ... programs range in nature from building reading or digital literacy skills to employment readiness seminars to fitness and health-centered activities" (p. 22). In Denmark, as circulation of physical books has decreased within recent years the number of visitors to public libraries has increased (Statistics Denmark, 2019). According to the Danish Library Association (2018), programs are part of the reason for the increased visitor numbers. Moreover, they attribute the rise in library use to a general tendency in society towards active participation in local communities. Thus, despite budget cuts and a feeling of general austerity within the public library sector, the current situations in both North America and Denmark suggest an increased and perhaps increasingly diverse use of public libraries and their services. This tendency can be described as a (re)turn to the multi-purpose ideal of the community-centered public library (Learned, 1924; Davies, 1974; Stauffer, 2016).

In tandem with the recent development of programs has been a growth in the practitioneroriented and experience-based writings on this topic (e.g. Edwards, Robinson and Unger, 2013; Bennett-Kapusniak, 2018). However, research literature has not kept pace with the growing importance of library programs. As stated by ALA (2017), "much anecdotal information about library programs exists", however, "we lack adequate (...) research to describe effective practices across the field" (p. 1). This article begins to address this gap in the literature by examining programs in public libraries in the United States, Canada, and Denmark, focusing specifically on programs with user fees. By drawing on previously collected data on public library programs offered in these three countries, this cross-national comparative study analyzes and discusses questions regarding not only fees, but also which library services are considered core services and which library services are considered special, peripheral or secondary.

Based on empirical data collected from Danish, Canadian, and U.S. public libraries, this article asks:

RQ1: How common is it for libraries to charge user fees for programs? 
RQ2: What (if anything) characterizes those libraries that charge fees for programs?

RQ3: What (if anything) characterizes programs with fees?

RQ4: What other types of limitations or restrictions do libraries place on program participation?

Answering these questions and comparing the answers by means of a comparative social policy approach (cf. Clasen, 2004), this article provides an empirical foundation for further research on the question of what it means if and when public libraries charge fees for programs.

\section{Literature Review}

The following section introduces key writings about user fees in public libraries. It also briefly introduces the history of library programs in North America and in Denmark with an eye towards changing conceptualizations of programs in libraries.

\section{Charging fees in public libraries}

The question of fees for public library programs can be productively understood within the context of literature on the ethics and economics of library fees. Three strands stand out when reviewing this literature: 1) user fees as an income generation strategy (Cartmill, 1992; Tilson, 1994); 2) the ethical questions of charging user fees (Cooper, 1978; Giacoma, 1989; Cartmill, 1992; Jaeger, 1999; Pautz, 2014; Pautz and Poulter, 2014); and 3) attitudes towards user fees (Shoham, 1998; Kinnucan, Estabrook, and Ferguson, 1998). This review considers the first two strands of literature, as they most directly inform the approach taken in this study.

According to Pautz (2014, p. 564-567), besides public funding, there are four common income sources for public libraries: fundraising, sponsorships, donations, and user fees. Focusing specifically on user fees, a study of public libraries in Israel concludes that "no statistical correlation was found between the size of library fees and library use" (Shoham, 1998, p. 44). However, the debate about charging user fees for library services is emotional and heated (Jaeger, 1999) because it touches upon the very foundation of the public library as a free public service. Fee opponents argue fees exclude some users and privilege others and therefore violate the "public library ethos" (Pautz, 2014, p. 561). Fee proponents argue that if the only way a public library can offer a service is by charging a fee, then it is advisable to do so (Shoham, 1998, p. 41). 
In a thorough literature review on income generation in public libraries, Pautz (2014) points out that although the 1972 UNESCO Public Library Manifesto specifies that "no direct charge should be made to anyone for its services" (IFLA, 1986, p. 57), this document is clear "only on the issue of free access to information services" (Pautz, 2014, p. 561). In other words, there is a clear consensus that information services should be free in libraries. There is less clarity about the ethics of charging users for, say, a dance class organized as a library program. In the Danish literature on public libraries, user fees have been a debated theme since the 1980s (see Thorhauge, 1997; Egholm and Jochumsen, 2000; Johannsen, 2004). These debates often appear in relation to database searches and Internet use. More recently, in North America, the question of fees for overdue materials has surged to the fore (e.g. Wood and Almeida, 2017). However, so far the topic of user fees for library programs has not been investigated.

\section{Programs in public libraries: A brief overview}

In Denmark, public libraries are mandatory for all municipalities and the central government provides legal guidelines for how to operate them. In contrast, public libraries in the U.S. and Canada have high degrees of autonomy in terms of their operations and are not generally seen as a mandatory public investment (Giacoma, 1989). An interesting contrast to the government regulations is that in Denmark programs are not framed as a mandatory public library service, whereas in the U.S., at least, programs are considered an "intrinsically essential library service" (American Library Association Public Programs Office, 2019, n.p.).

The term "programs" has been used in North American librarianship since at least the 1950s (Steinbarger, 1951). In the 1990s, the ALA created the Public Programs Office, and the term "programming librarian" emerged (e.g. Brown, 1992). Programming librarianship has since become a "professional designation and specialty" (National Impact of Library Public Programs Assessment, 2014, p. 3). A survey of 716 public libraries conducted by the U.S. Public Library Association in 1977 found some libraries charging fees for "admission to library-sponsored programs" (Giacoma, 1989, p. 3) as well as for other services such as the use of copying machines and meeting rooms. Thus, charging fees for library programs is not a new phenomenon, despite the fact that this topic has not previously been addressed in its own right by the research literature.

In Denmark, programs known as "cultural activities" (kulturelle arrangementer) or simply "activities" (arrangementer) have been part of Danish public libraries since the nineteenth century 
(Dahlkild and Danmarks Biblioteksforening, 2011, p. 15). However, programs have increasingly become part of the library services since the revision of the library Act in 1964, where the mission statement was revised to include the provision of enlightenment, education and cultural activity (Thorsen, 1992). Like other public institutions in Denmark, public libraries are state-funded as part of the welfare state model and as such part of the cultural infrastructure largely supported by taxes. The welfare state model is influenced by what is known as "the no-charge principle" (gratisprincippet), which was introduced in Danish public libraries in the 1950s as the general "doxa" behind public services (Harbo, 1987). Originally, programs in public libraries were also covered by this principle (Thorsen, 1992). However, in the 1983 revision of the library Act, public libraries were allowed to charge entrance fees for program participation as well as to charge fines when returning books too late (Harbo, 1987, p. 20). According to the current Act on public libraries from 2000, "[i]t is a basic principle in the Danish welfare society that using the library is free, including interlibrary loans (...) However, it is possible for the libraries to charge for special services such as instruction, courses and other learning activities (...)" (Thorhauge and the Library Agency, 2002, p. 6, emphasis added). Thus, the distinction between core and special services seems to be the reasoning behind charging user fees for programs in Danish public libraries.

Summing up, although debates on user fees and other income generating methods have been part of the library profession and research field in both North America and Denmark, the particular topic of user fees for library programs has up to now evaded scholarly scrutiny. This is despite the fact that programming is becoming - or may already have become - central to the identity of the modern public library.

\section{Methods}

This article builds upon empirical data collected during two independently conducted research projects on public library programs in North America and Denmark. Although the studies were initially conducted individually and for different purposes, several points of comparison exist between the two studies, including the question of user fees for program participation. The two datasets both consist of qualitative information that can be quantified to answer specific questions and to examine tendencies. 
In the presentation of data, this article draws upon the tradition of comparative social policy studies (Clasen, 2004; Kennett 2004), which, at a methodological level, focuses on problems of cross-national comparison "generating comparable data [and] identifying appropriate functional equivalents" across different national contexts (Clasen, 2004, p. 74). This methodology should be understood as residing within the more qualitative and exploratory oriented approaches to social phenomena in the sense that the goal is to illuminate new topics and not to pin down definitive results. Thus, in this article, comparative analysis is applied in relation to comparative social policy as a research strategy to illuminate specific questions and hypotheses. In the present study, the comparative analysis began from the identification of the fact that in both datasets information existed on public library programs that had user fees associated with them. Asking new questions using this pre-existing data, the authors then used a focused coding process to discern features of different public libraries and of different programs that had user fees. This process answered the research questions posed, and raised new ones, sketched in the discussion section below.

\section{Study 1: North America}

In spring 2017, public libraries throughout North America were invited to self-select for participation in an online survey on movement-based programs they had offered, such as walking, dancing, yoga, or gardening programs (AUTHOR, 2017). Data collection was carried out via an online questionnaire using Qualtrics. The URL to the questionnaire was sent to state and provincial library electronic mailing lists, as well as through announcements from state and provincial libraries. In addition, the survey was disseminated through national electronic mailing lists and on the project's website. Between February 14 and March 23, 2017, a self-selecting sample of 1,157 public libraries completed the survey, after incomplete and duplicate responses were removed. Although by no means providing a representative sample of the population surveyed, this means of data collection offers unique opportunities to explore poorly understood phenomena (Friedman, O'Brien, and Laurison, 2017). In the context of the present study, the most significant question in the survey is question 18, which asked respondents to indicate whether programs they offer "sometimes or always require participants (select all that apply): a) Register in advance, b) Sign a waiver of liability, c) Pay a fee, d) Do something else, e) No requirements for participation, f) Don't know." In the present study, public libraries that indicated they offered programs with user fees were then more closely analyzed to answer this study's research questions. Particular attention 
focused on the information responded provided about their library's locations, which were then integrated into U.S. and Canadian statistics on community demographics, and on the types of movement-based programs they offered that had user fees associated with them (an abbreviated version of the questionnaire that includes questions considered in this study can be found in Appendix 1).

\section{Study 2: Denmark}

The dataset from Denmark consists of 844 Facebook events announcing public library programs. The data was collected in February 2018 as part of a larger study and comprise both textual data and metadata connected to the Facebook events. The original study aimed to collect a diverse sample of public library Facebook pages by using both probability sampling to increase external validity and purposive sampling to increase transferability (see Teddlie and $\mathrm{Yu}, 2007$ ). In Denmark, public libraries are mandatory for all municipalities and the municipalities are in charge of the public libraries. Therefore, as a first sample, the 98 Danish municipalities representing 98 library systems were divided into strata by classifying them according to the four municipality types urban, medium, rural and peripheral. Then, using national statistics collected by the Ministry of Economic Affairs and the Interior (noegletal.dk), searches on each of the four municipality types were conducted focusing on one criteria: public library expenses per citizen. The search results are used to divide the municipalities in another strata according to three subcategories of library budgets: above average, average and below average. Finally, from each of the four municipality types, the three municipalities with the lowest budgets, the highest budgets and the budgets closest to average were selected. In this selection, the overall sample of 98 was narrowed down to a sample of 36 library systems varying according to municipality type and library budget. Then follows a purposive sampling of a small number of cases within each strata to provide a diverse body of data. In addition to municipality type and budget, geographical location and the size of the library system are added as criteria behind the purposive sampling as well as information on how long Facebook has been used for announcing programs. From these 36 municipalities, 12 Facebook pages were selected, representing 12 public library systems and no less than 48 public libraries.

The data from the public library Facebook pages was collected using screen capturing and harvesting via API as methods of web archiving. Every kind of program announced in the Facebook events were included in the data collection, which resulted in a total of 2793 Facebook 
events and descriptions from 2011 until December 2017. The textual data is all written in Danish and in the original study the data has been coded in Danish using categories, which are then translated to English. For this comparative article, only the data from 2017 is used. The textual data includes information about the formal circumstances behind the programs (such as location, duration and organizers behind the event) as well as detailed descriptions of the content and sometimes the function of the programs. These details were found in the event titles and event descriptions. Beside descriptions of the content and function of the programs, the textual data found in the event descriptions include information about access and availability such as registration, prices and other limitations or restrictions, which is useful for the present study.

\section{Limitations}

It should be stressed that both datasets are just small pieces of much larger studies. In neither study was randomized sampling a goal. Therefore, this study should be seen as highly exploratory, with tentative findings based on the comparison of data from two individually conducted studies. All the limitations of the two original studies are compounded when compared. In the North American study, only movement-based programs were studied whereas in the Danish study only a limited number of public library Facebook pages were selected and only the programs announced on these pages were collected. Nevertheless, this approach fits within the framework of comparative social policy studies. This framework seeks to discern trends across national boundaries, frequently by comparing heterogeneous data-sets. Nonetheless, despite these limitations, this study opens new avenues for research on the question of user fees and public library services.

\section{Results}

How common is it for libraries to charge user fees for programs?

Of the 1,157 public libraries that responded to the North American survey, 99 (8.5\%) reported requiring participants to pay a fee to participate in a program sponsored by their library. Respondents were also asked to specify which, if any, of their programs had fees associated with them. Framed this way, only $143(4 \%)$ of the 3,940 movement-based programs offered by the 1,157 respondents had fees associated with them. It is more common for Danish public libraries to charge fees for program participation: 224 (27\%) or approximately one fourth of the 844 programs charged a fee. Unlike the North American study, the Danish study has data not only on the presence 
or absence of fees but also the amount of those fees. To analyze the different prices mentioned in the data, three categories of price ranges are developed: modest (1.5-6 USD), considerable (7-15 USD) and costly (16-42 USD). The programs with fees are then classified according to these three categories. Of the 224 programs charging a fee, 88 (39\%) are classified as modest fees, 118 (53\%) as considerable fees and $18(8 \%)$ as costly fees.

Based on a comparison of findings from the two studies, one can tentatively conclude that fees for programs are more common in a Danish context than in a North American context and that there is a substantial variation in the fees charged for programs in Denmark.

What (if anything) characterizes those libraries that charge fees for programs?

In the North American survey, postal codes were collected, which enables sorting respondents along an urban-rural continuum as well as within different regions (Table 1). Based on this classification, it appears that suburban libraries are more likely than their urban counterparts to charge fees and that charging fees is more common in the Mid-Atlantic and Midwest than elsewhere on the continent.

[Table 1]

Table 1: Number of North American public libraries that charged fees, by community type and by region.

In the Danish study, a criterion for data sampling was to include all four municipality types, all five regions, and a diverse variety of library budgets per citizen. Classifying the data according to these variations, no sizable differences are found. This finding suggests a uniform approach to program fees across Denmark. When comparing the libraries according to budget sizes alone, certain differences appear. Libraries with above average budgets appear to be more likely to charge fees for programs than libraries with budgets around or below average. Hence, 119- or more than half of the 224 programs with a fee - took place within or in relation to libraries with above average budgets, whereas only 25 out of 224 programs were to be found in relation to low budget libraries. This finding should be seen in the relation to the fact that libraries with better funding generally have more programs: $53 \%$ of the 884 programs described in the data take place in relation to libraries with above average budgets. Considering this finding, it is quite interesting that libraries with budgets below the national average generally charge the highest fees (Table 2). 
[Table 2]

Table 2: Number of fees in the Danish study classified according to price range and sorted by budget size.

[Figure 1]

Figure 1: Cross comparison of libraries that charge fees for programs sorted by municipality/community type.

To answer RQ2, the situation looks quite different when comparing public libraries that charge fees for programs in North America and Denmark. When comparing the two studies according to the urban-rural continuum (Figure 1), it appears that libraries in Danish urban municipalities are most likely to charge fees for programs, which is the complete opposite of the findings from the North American study. Libraries in Danish rural areas are also quite likely to charge fees for programs, whereas libraries in rural communities in North America are more similar to their counterparts in towns. A possible conclusion to draw from this comparison is that what characterizes the libraries that do charge fees for programs appear to be fairly country and even region specific. Again, the need for more thorough research is stressed, including investigations of the reasoning behind and practices of charging user fees for public library programs.

\section{What (if anything) characterizes programs with fees?}

In the North American study, respondents were asked to indicate what types of programs they offer, and then whether or not those particular types of programs had fees associated with them. In the 99 libraries that reported programs with fees, 143 specific programs were mentioned. Tai Chi and Yoga appear to be the types of programs most likely to have fees: $11 \%$ of the 232 libraries that offer Tai Chi programs charge a fee (Figure 2).

[Figure 2]

Figure 2: Programs offered by North American libraries that have fees associated with them. 
In the Danish study, 178 (79\%) of the 224 programs with fees are intended for an adult audience, while $46(21 \%)$ are intended for children, young people or families. The dominance of adult programs among those with fees is even more apparent when considering the different price ranges; only 2 out of 18 programs with costly fees, 9 out of 118 programs with considerable fees, and 36 out of 88 programs with modest fees are intended for children. Considering the different types of programs, programs with modest fees are lectures and writer's meetings, workshops and children's theatre. programs with considerable fees are lectures and writer's meetings, concerts and workshops, including IT-courses. Most programs with costly fees are concerts, including shows and dancing. Lectures and writer's meetings are also among the costly programs and, as opposed to the less expensive lectures and writer's meetings, these are characterized by featuring quite well-known speakers.

Answering RQ3, both studies suggest that programs, which require more than library staff time, such as programs with instructors or invited speakers, are more likely to have fees associated with them, compared to programs that can be done entirely by library staff. Concerning the finding that in North America library programs for children were least likely to charge fees, in the Danish study, although programs for children do often come with fees, these fees most often belong to the modest price range. However, a need for further investigation into the broad spectrum of different prices is identified.

\section{What other types of limitations or restrictions do libraries place on program participation?}

Programs do not have user fees but can still have other types of access restrictions. In the North American study, paying a fee emerged as the least likely limitation a library will impose on its programs. Here, librarians were asked about other things patrons have to do to participate in a library program, including a) register, b) sign a waiver of liability, c) pay a fee, and/or d) do something else. On average, 35\% of all programs (excluding passive programs like StoryWalks) reported requiring advance registration. On average 15\% require waivers be signed, only $4 \%$ required paying a fee, and only $2 \%$ said participants had to do something else to participate. By this calculation, it appears that if there are any limitations on programs, it tends to be signing up in advance or signing a document: you cannot simply drop-in and participate in many of these programs in North American libraries. This is an interesting finding in relation to the Danish data, where programs inviting users to "drop-in" without any sort of registration appear to be quite 
normal. The most common type of limitation found in the Danish data is the need for registration in advance. Other less common limitations or restrictions are the need for memberships, the need to bring something to a program (e.g. a blanket, a screwdriver, a lunch pack or a crochet needle) or the requirement of a specific skills (e.g. for crochet work).

In their study, AUTHOR (2019: 869) introduce the idea of an "Access Continuum" for analyzing the broad spectrum of limitations and restrictions found in relation to program participation in public libraries in Denmark. As an answer for RQ4, a modified version of the "Access Continuum" serves as an illustration of the broad and complex variety of restrictions and limitations found in both studies (Figure 3). From programs with free entrance, which are open for all, to programs with limited access that require paying a fee, a membership, specific skills, signing a waiver or registration in advance. In between these poles are multiple other combinations. Combining the findings from both studies in the modified version of the "Access Continuum", the model becomes a useful analytical tool for discussing and comparing the access and availability of programs in an international and cross-national context.

[Figure 3]

Figure 3: Modified version of the "Access Continuum" (in AUTHOR, 2019: 869).

\section{Discussion}

The data for this article has numerous limitations, not least of which is the fact that it derives from two distinct studies; one focusing on a specific type of program (programs involving the movement of the body) and another on all types of programs (announced publicly online). Thus, further research on the questions raised in this article is needed. If data were rigorously collected for comparative analysis, it would enable conclusions that are more generalizable. Nonetheless, given this study's orientation in exploratory comparative social policy studies (cf. Clasen, 2004, Kennett 2004), certain implications can be discerned and discussed.

An important finding from this article is that the fees charged by public libraries for program participation are only a small part of the limitations and restrictions users meet when wanting to participate in a program. As illustrated in the "Access Continuum" (Figure 3), both studies revealed that in addition to fees, many programs have other requirements for participation, 
spanning the range from advance registration, to signing documents or bringing particular items to the program. A broad spectrum of factors may play into the relative accessibility and availability of programs. As an area of research, the question of user fees for program participation touches upon essential questions, including what to consider as core or peripheral library services, and to what extent these different services are - in fact - freely and equally accessible for all?

Why do public libraries charge fees for programs? This article does not provide any final answers for this question but the reasons. However, anecdotal information suggests that charging fees can be a way to ensure the people signing up for a program do in fact show up. One could argue that the bigger the entrance fee the more you feel obliged to attend or the less you want to miss out on the money already spent. When writing this article, the authors came across an interesting example of how to avoid people not showing up for programs to which they had signed up: A public library in Great Britain was charging deposits for programs. Attending a program to which you have paid, your $£ 6$ deposit (approximately 7.6 USD) is returned to you (Westminster Reference Library, 2019). In any case, more research is needed on the rationales that underlie the charging of user fees for programs, as well as how library patrons perceive those fees.

The idea of fees for programs challenges one of the public library's core values, the "public library ethos" (Pautz, 2014, p. 561) that centers on free and equal access for all. This is why the "fee vs free" debate is among the most contested (and long-lasting) ethical issues within the literature (Giacoma, 1989; Jaeger, 1999; Pautz, 2014; Wood and Almeida, 2017). Less discussed is the question of whether or not this principle should (or could) cover everything a library offers. Returning to the introductory quote by Shoham (1998, p. 40), the finding that some public library services have fees and others do not is part of a much larger context. In order to study this context, additional research could productively probe the political, economic, social and technological (PEST) conditions surrounding the levying of user fees for library programs, as suggested by past research (Michnik, 2015). One possible PEST analysis could consider how differences in the political economies of Denmark, the United States, and Canada influence decision-making regarding user fees. In Denmark, there is a paradox. On the one hand, there is the expectation by the welfare state that all public services should be free without limitation. On the other hand, it is still possible within this framework to have "special" services that are not free, with shifting ideas over time about what is core (and thus must be free) and what is special. This is perhaps the reason why this study found them to be more likely than their North American counterparts to do so. In 
North America, in contrast, there is a greater emphasis on the rights of local jurisdiction to decide how to run local governmental services, including even whether or not to have a public library. In this context, the issue is more of a "local" matter. These findings suggest that programs in general in Denmark, and movement-based programs in particular in North America, may be seen by library professionals and funders as special types of public library services - distinct from the core or center of the public library as an institution. This tentative conclusion requires further research as well as further theoretical discussion and development. Moreover, the differences regarding public library services and how they reflect different political, economic, social and technological conditions, deserve further enquiry.

\section{Conclusion}

In this article, public library programs were studied as part of library services in North America and Denmark. In particular, the question of user fees for program participation was queried based on data collected in two individually conducted studies. The comparative analysis showed both similarities and deviations regarding the levying of fees for library programs. In any case, the need for more research on the political, economic, social and technological conditions behind charging fees for public library programs is emphasized.

Despite the fact that there is clear evidence that programming is becoming more central to the identity of the public library, discussion of fees for programs has largely been absent from both research and professional debates. This article explores a previously under-studied facet of contemporary public librarianship and opens up new avenues for inquiry regarding how the particular policies of particular libraries relate to theoretical discussions about programs as public library services.

\section{References}

American Library Association. (2017), "National Impact of Library Public Programs Assessment Proposal," available at: https://www.imls.gov/sites/default/files/grants/lg-96-17-004817/proposals/lg-96-17-0048-17-full-proposal-documents.pdf (accessed 5 August 2019). American Library Association. (2018), "From Awareness to Funding: Voter Perceptions and Support of Public Libraries in 2018," available at: https://www.oclc.org/research/awareness-to-funding-2018.html (accessed 5 August 2019). 
American Library Association Public Programs Office. (2019), "Programming Librarian Interest Group,” available at: http://programminglibrarian.org/about/programming-librarianinterest-group (accessed 5 August 2019).

Bennett-Kapusniak, R. (2018), Public library programs and services for midlife and beyond, Libraries Unlimited, Santa Barbara.

Brown, B. (1992), Programming for librarians, a how-to-do-it manual, Neal-Schuman, New York.

Cartmill, D. (1992), “Charging for public library services,” Library Management, Vol. 13 no. 6, pp. $25-41$.

Clasen, J. (2004), “Defining comparative social policy,” Kennett, P., A handbook of comparative social policy, Edward Elgar Publishing, Cheltenham, pp. 71-83.

Cooper, M. (1978), “Charging users for library service,” Information Processing and Management, Vol. 14 No. 6, pp. 419-427.

Dahlkild, N. and Danmarks Biblioteksforening. (2011), Biblioteket i tid og rum, arkitektur, indretning og formidling, Danmarks Biblioteksforening, Copenhagen.

Danish Library Association. (2018), "Bibliotekernes besøgstal stiger og servicen hitter," [The library's visitor numbers are growing and the service is a hit], available at: https://www.db.dk/bibliotekernes-service-hitter (accessed 6 August 2019).

Davies, D.W. (1974), Public Libraries as Culture and Social Centers: The Origin of the Concept, Scarecrow Press, Metuchen, N.J.

Edwards, J. B., Robinson, M. S., and Unger, K. R. (2013), Transforming libraries, building communities: The community-centered library, Scarecrow Press, Lanham.

Egholm, C. and Jochumsen, H. (2000), "Perspectives concerning user fees in public libraries," Library Management, Vol. 21 No. 6, pp. 298-306.

Friedman, S., O’Brien, D. and Laurison, D. (2017), “'Like skydiving without a parachute': How class origin shapes occupational trajectories in British acting," Sociology, Vol. 51 No. 5, pp. 992-1010.

Giacoma, P. (1989), The fee or free decision, legal, economic, political, and ethical perspectives for public libraries, Neal-Schuman Publishers, New York. 
Harbo, Ole (1987), "Gratis ydelser og betalinger ved danske biblioteker i fortid og nutid," Christoffersen, H. Harbo, O. Holmquist A.-M. and Nielsen, E., Betaling og bibliotek, Danmarks Biblioteksforenings Forlag, Copenhagen, pp. 9-25.

IFLA. (1986), “Guidelines for public libraries,” IFLA section of public libraries, The UNESCO Public Library Manifesto, IFLA Publications 36, KG Saur, Munich, pp. 57-60.

Institute of Museum \& Library Services (2019), "Public Libraries in the United States Survey: Fiscal Year 2016," available at: https://www.imls.gov/publications/public-libraries-unitedstates-survey-fiscal-year-2016 (accessed 6 August 2019).

Jaeger, J. (1999), "User Fees, Community Goods, and the Public Library," Public Library Quarterly, Vol. 17 No. 2, pp. 49-62.

Johannsen, C. Gustav (2004), Managing fee-based public library services: Values and practices, Library Management, Vol. 25 No. 6/7, pp. 307-315.

Kennett, P. (Ed.). (2013), A handbook of comparative social policy (2nd ed.), Edward Elgar Publishing, Cheltenham.

Kinnucan, M., Estabrook, L. and Ferguson, M. (1998), "Public Opinion toward User Fees in Public Libraries," Library Quarterly, Vol. 68 No. 2, pp. 183-204.

Learned, S. (1924), The American Public Library and the Diffusion of Knowledge, Harcourt, Brace and Company: New York.

AUTHOR. (2017), "Movement-based programs in US and Canadian public libraries: Evidence of impacts from an exploratory survey," Evidence Based Library and Information Practice, Vol 12 No. 4, pp. 214-232.

AUTHOR. (2019), "Researching public library programs through Facebook events: a new research approach," Journal of Documentation, Vol. 75 No. 4, pp. 857-875.

Michnik, K. (2015), "Public library managers' descriptions of political attention,” Library Management, Vol. 36 No. 8/9, pp. 673-684.

National Impact of Library Public Programs Assessment. (2014), "National Impact of Library Public Programs Assessment," available at: https://nilppa.org/wpcontent/uploads/2014/NILPPA_White_Paper_FINAL_web.pdf (accessed 6 August 2019). Pautz, H. (2014), "Income generation in public libraries: Potentials and pitfalls," Library Review, Vol. 63 No. 8/9, pp. 560-573. 
Pautz, H. and Poulter, A. (2014), "Public libraries in the "age of austerity": income generation and public library ethos," Library and Information Research, Vol. 38 No. 117, pp. 20-36.

Shoham, S. (1998), "Fees in Public Libraries,” Public Library Quarterly, Vol. 17 No. 1, pp. 3948.

Stauffer, S. (2016), "Supplanting the saloon evil and other loafing habits: Utah's librarygymnasium movement, 1907-1912," The Library Quarterly, Vol. 86 No. 4, pp. 434-448.

Steinbarger, H. (1951), “The Role of Libraries in Adult Education,” Adult Education, Vol. 1 No. 6, pp. 228-233.

Statistics Denmark (2019), Available at: https://www.statistikbanken.dk/statbank5a/selectvarval/saveselections.asp (accessed 6 August 2019).

Teddlie, C. and Yu, F. (2007), "Mixed Methods Sampling: A Typology With Examples," Journal of Mixed Methods Research, Vol. 1 No. 1, pp. 77-100.

Thorhauge, J. (Ed.). (1997), Bibliotek og betaling, synspunkter på en aktuel problematik: Indloeg på Biblioteks-paraplyens konferencer om bibliotek og betaling, Danmarks Biblioteksforenings Forlag, Ballerup.

Thorhauge, J. and the Library Agency (Eds.). (2002), Danish library policy, a selection of recent articles and papers, Biblioteksstyrelsen, Copenhagen.

Thorsen, L. (1992), De Danske Folkebiblioteker 1940-1983, Dansk BiblioteksCenter, Ballerup. Tilson, Y. (1994), "Income Generation and Pricing in Libraries," Library Management, Vol. 15 No. 2, pp. 5-17.

Westminster Reference Library. (2019), accessed at: https://witter.com/WestRefLib/status/1125703821341016064 (accessed 6 August 2019).

Wood, E., and Almeida, J. (2017), "If we charge them, will they come? Fostering positive relationships with students by remaining fine-free," Reference \& User Services Quarterly, Vol. 56 No. 3, pp. 158-161.

Appendix 1: Excerpts from questionnaire used in North American study. The full version of this questionnaire can be found in AUTHOR, 2017.

Q1. These questions ask for some background information on your library. What is the zip code, or postal code, of your library's physical location? 
Q3. Has your library ever offered any programs or services that include (select all that apply)? [Note: Responses to Q3 were carried forward for the remainder of the survey] Movement-based programs for early literacy (e.g. Music and Movement) Yoga

Tai Chi

Zumba

Dancing

Walking, hiking, bicycling, or running

StoryWalks

Gardening

Fitness challenges (e.g. pedometer challenge, biggest loser programs, Couch to $5 \mathrm{~K}$ )

Fitness equipment that can be checked out, including passes for gyms or aquatic centers Other programs or services

No programs or services involving movement

Q18. For the following programs and services, are any of the following ever required? (select all that apply). [Carried forward programs from Q3] sometimes or always require participants:

Register in advance

Sign a waiver of liability

Pay a fee

Do something else

No requirements for participation

Don't know 


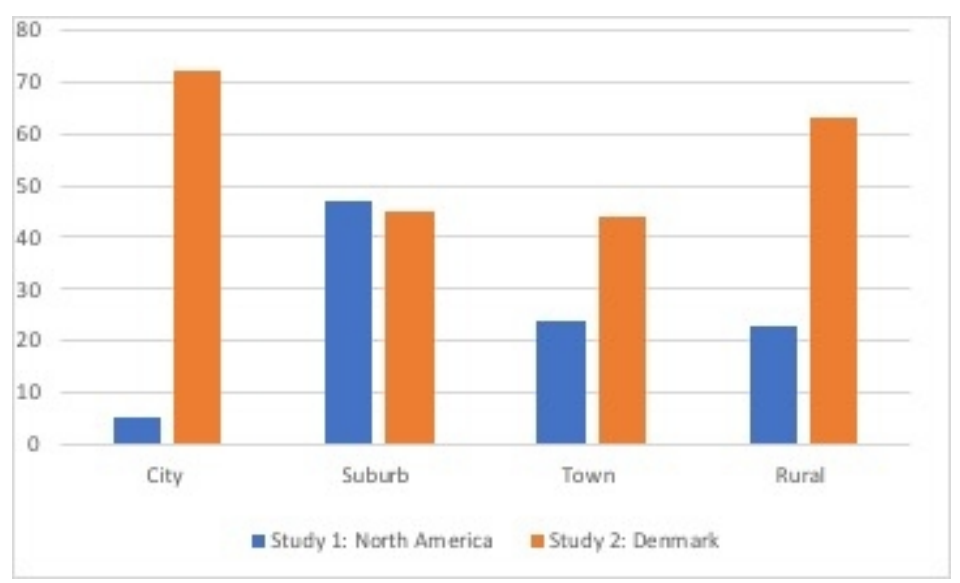

Figure 1: Cross comparison of libraries that charge fees for programs sorted by municipality/community type.

$127 \times 76 \mathrm{~mm}(72 \times 72 \mathrm{DPI})$ 
1

2

3

4

5

6

7

8

9

10

11

12

13

14

15

16

17

18

19

20

21

22

23

24

25

26

27

28

29

30

31

32

33

34

35

36

37

38

39

40

41

42

43

44

45

46

47

48

49

50

51

52

53

54

55

56

57

58

59

60

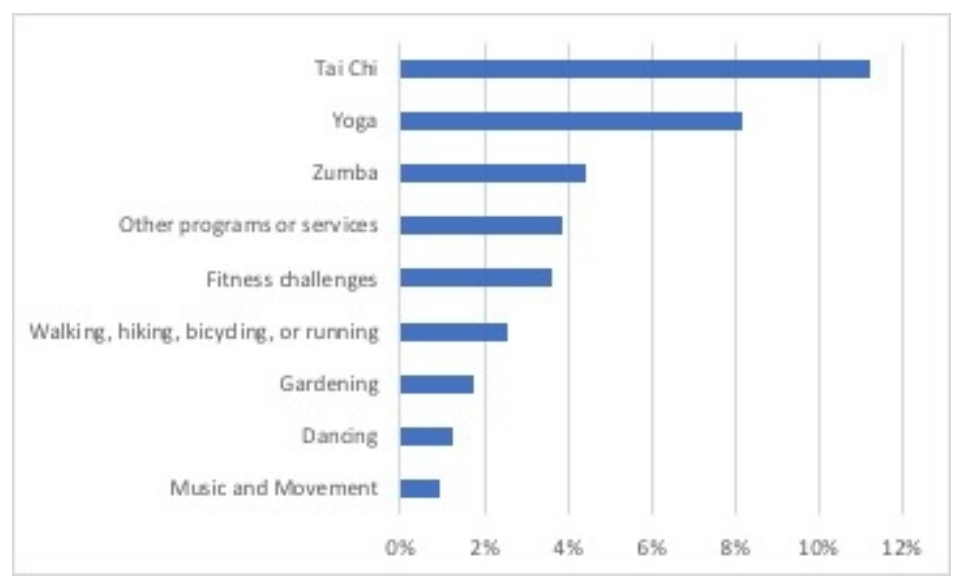

Figure 2: Programs offered by North American libraries that have fees associated with them.

$127 \times 76 \mathrm{~mm}(72 \times 72 \mathrm{DPI})$ 


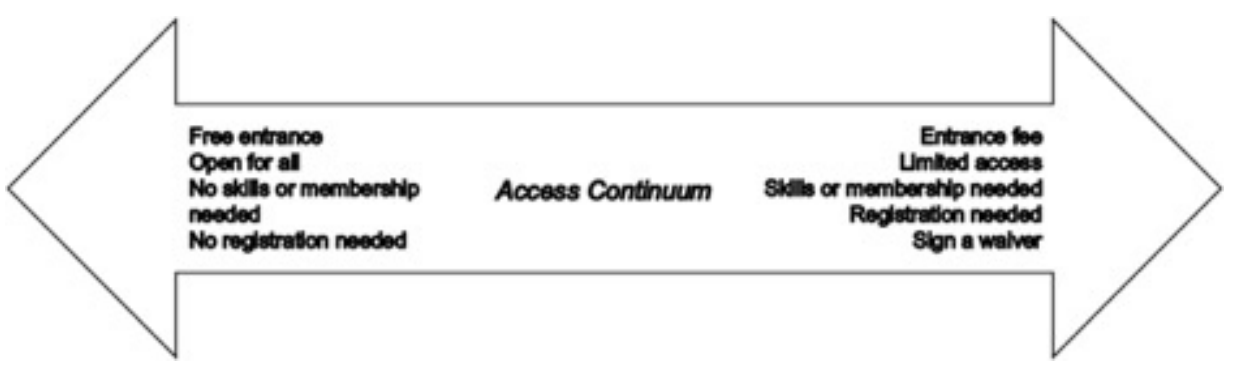

Figure 3: Modified version of the "Access Continuum" (in AUTHOR, 2019: 869).

$$
165 \times 46 \mathrm{~mm}(72 \times 72 \mathrm{DPI})
$$




\begin{tabular}{r|ll} 
& \multicolumn{1}{c}{ Sample } & \multicolumn{1}{c}{ Charged a Fee } \\
\hline City & $204(17.6 \%)$ & $5(5.1 \%)$ \\
Suburb & $419(36.2 \%)$ & $47(47.5 \%)$ \\
Town & $327(28.2 \%)$ & $24(24.2 \%)$ \\
Rural & $207(17.9 \%)$ & $23(23.2 \%)$ \\
Total & $1157(100 \%)$ & $99(100 \%)$ \\
& & \\
& Overall Data & Charged a Fee \\
New England & $171(14.8 \%)$ & $10(10.1 \%)$ \\
Mid East & $162(14 \%)$ & $31(31.3 \%)$ \\
Great Lakes & $216(18.7 \%)$ & $25(25.3 \%)$ \\
Plains & $142(12.3 \%)$ & $9(9.1 \%)$ \\
South East & $210(18.2 \%)$ & $14(14.1 \%)$ \\
South West & $62(5.4 \%)$ & $2(2.0 \%$ \\
Rocky Mountains & $49(4.2 \%)$ & $1(1.0 \%)$ \\
Far West & $83(7.2 \%)$ & $4(4.0 \%)$ \\
Canada & $62(5.4 \%)$ & $3(3.0 \%)$ \\
Total & 1157 & 99
\end{tabular}

Table 1: Number of libraries in study 1 that charged fees, by community type and by region. 


\begin{tabular}{r|lllll} 
& Modest & Considerable & Costly & Average price & Total \\
\hline Above average budgets & 56 & 58 & 5 & 7.7 USD & 119 \\
Average budgets & 25 & 46 & 9 & 9.7 USD & 80 \\
Below average budgets & 7 & 14 & 4 & 11.6 USD & 25 \\
Total & & & & & 224
\end{tabular}

Table 2: Number of fees classified according to price range and sorted by budget size. 